\title{
THE POSSIBILITIES AND LIMITATIONS OF GEOSTATISTICAL METHODS IN REAL ESTATE MARKET ANALYSES
}

\author{
Radosław Cellmer, PhD \\ Faculty of Geodesy and Land Management \\ University of Warmia and Mazury in Olsztyn \\ e-mail:rcellmer@uwm.edu.pl
}

\begin{abstract}
In the traditional approach, geostatistical modeling involves analyses of the spatial structure of regionalized data, as well as estimations and simulations that rely on kriging methods. Geostatistical methods can complement traditional statistical models of property transaction prices, and when combined with those models, they offer a comprehensive tool for spatial analysis that is used in the process of developing land value maps. Transaction prices are characterized by mutual spatial correlations and can be considered as regionalized variables. They can also be regarded as random variables that have a local character and a specific probability distribution.

This study explores the possibilities of applying geostatistical methods in spatial modeling of the prices of undeveloped land, as well as the limitations associated with those methods and the imperfect nature of the real estate market. The results are discussed based on examples, and they cover both the modeling process and the generated land value maps.
\end{abstract}

Keywords: real estate market, geostatistics, semivariogram, kriging.

JEL Classification: C18, R32.

Citation: Cellmer R., 2014, The possibilities and limitations of geostatistical methods in real estate market analyses, Real Estate Management and Valuation, vol. 22, no. 3, s. 54-62.

DOI: $10.2478 /$ remav-2014-0027

\section{Introduction}

The real estate market can be described as a general set of rules for transferring rights to property and concluding agreements that establish mutual rights and obligations associated with property ownership (KUCHARSKA-STASIAK 1999). Market analyses can have different goals, but their main purpose is to explain the factors determining demand, supply and, consequently, transaction prices. In analyses aiming to determine the market value of property, the main focus is on conditions and factors that shape transaction prices. Traded property occupies a given area in space; therefore, it can be assumed that information pertaining to a transaction has a spatial character (KULCZYCKI, LIGAS 2007). Real estate market events can be mass phenomena, which justifies the use of geostatistical methods in market analyses. In this case, the key analyzed metric - the transaction price - is regarded as a regionalized variable. According to MATHERON (1971), regionalized variables combine the features of random and deterministic variables. They are characterized by mutual spatial correlations, and can also be regarded as local random variables with specific probability distribution. Classical statistical methods account for complete randomness of errors, whereas structure is represented by deterministic expressions (NAMYSŁOWSKA-WILCZYŃSKA 2006). For a more accurate representation of reality, transaction prices could be regarded as regionalized variables, and randomness could be expressed under fluctuating conditions that do not constitute errors, but are descriptors of a given phenomenon, which have a specific structure. The above approach is justified by the fact that 
transaction prices represent specific amounts of money paid for property, and they cannot be regarded as a physical phenomenon that is measured with a certain error.

Geostatistical methods are applied in real estate market analyses to address spatial autocorrelations between transaction prices. In accordance with Tobler's first law of geography, all geographic objects share certain similarities, but their similarity decreases with an increase in distance between these objects (LONGLEY ET AL. 2005). Similar locations, socioeconomic and spatial factors generate similar transaction prices. The distinctive features of a given location apply to numerous properties in the neighborhood. They include socioeconomic factors, spatial factors relating to the use of space, availability, distance from the workplace, local amenities and inconveniences (BASU and THIBODEAU 1998). The correlations between observations are a function of distance separating the analyzed objects, and those dependencies are generally regarded as isotropic (DUBIN 2003). The assumption that spatial autocorrelations exist between transaction prices on the real estate market constitutes a basis for the application of geostatistical methods, and it supports the evaluation of the spatial structure of prices to determine similarities between properties based on their location (TU et al. 2007).

\section{Geostatistical methods}

Classical statistical methods applied in market analyses make only indirect use of spatial information by, for example, relying on location variables whose value is often defined arbitrarily. Geostatistical methods analyze random events in view of their spatial characteristics. They provide tools for describing spatial continuity and expand the possibilities of regression models by incorporating spatial continuity in the model. These methods interpret and predict the spatial distribution of the analyzed phenomena (ZAWADZKI 2005, SARMA 2009). The basic functions of geostatistical methods are analysis and modeling of the spatial and spatio-temporal structure of phenomena, estimation, simulation and optimization (STACH 2009).

One of the fundamental premises in geostatistics is the similarity in the values of the analyzed variable as a function of distance. The structure of variations in a regionalized variable is described by a function known as the variogram. A variogram describes the variance in variable values resulting from differences in the analyzed phenomenon in different locations. In a variogram, every pair of locations is analyzed twice; therefore, the variation in variable values resulting from the distance between the measured sample points is described with a semivariogram, which refers to half the variogram. An empirical semivariogram can be calculated with the use of the below formula (CRESSIE 1993, SARMA 2009):

$$
r(h)=\frac{1}{2 N(h)} \sum_{i=1}^{N(h)}\left[Z\left(x_{i}+h\right)-Z\left(x_{i}\right)\right]^{2}
$$

where:

$\mathrm{Z}\left(x_{i}\right) \quad$ - value of data

$x_{i} \quad$ - locations were measurements were performed

$N(h) \quad$ - number of pairs of points $\left(x_{i}, x_{i}+h\right)$ separated by distance $h$

An empirical semivariogram is approximated by conditionally negative definite functions (ISAAKS, SRIVASTAVA 1989; CHILES, DelFINER 1999), mostly linear, spherical, exponential or Gaussian models. The semivariogram function illustrates the rate at which mutual interactions between variables decrease with an increase in distance.

Geostatistical methods are applied to estimate the value of the analyzed attribute in a given location based on observations (or measurements) performed at several points with known coordinates. In most kriging interpolation approaches, this value is calculated as a linear combination of regionalized random variables:

$$
Z^{*}\left(s_{0}\right)=\sum_{i=1}^{n} w_{i} Z\left(s_{i}\right)
$$

where: $\mathrm{Z}^{*}\left(\mathrm{~s}_{0}\right)$ is the estimated value, $\mathrm{Z}\left(\mathrm{s}_{\mathrm{i}}\right)$ represents the values observed in known locations, and weights $\mathrm{w}_{\mathrm{i}}$ account for the distance between data and data estimation locations, their spatial configuration and spatial structure described by a theoretical semivariogram. 
Kriging is a geostatistical method that provides the best linear unbiased estimators of the value of the analyzed regionalized variable. It is often described with the use of the BLUE (best linear unbiased estimator) acronym. Kriging supports the identification of regularities in spatial distribution of data, and those regularities are used in spatial interpolation. Kriging methods are applied to quantitative data expressed on a quotient scale or an interval scale (LONGLEY et al. 2005). Kriging was developed by Danie G. Krige, who pursued the moving average concept in statistical interpolation methods to remove the effect of regression in estimating mineral resources (KRIGE 1951, 1962; NAMYSŁOWSKAWILCZYŃSKA 2006). The proposed methods were further developed and described in detail by MATHERON $(1963,1971)$. The most popular kriging estimators include ordinary kriging, which is used when the average value is constant and unknown, and simple kriging, which is applied when the average value is known. Other kriging methods include universal kriging and non-linear kriging techniques such as disjunctive, probability and indicator kriging, which differ in their assumptions. The cokriging method is used when more than one principal variable is applied in spatial interpolation.

In comparison with other methods, geostatistical techniques are rarely applied in spatial analyses of the real estate market. The possibilities offered by geostatistical methods in market analyses have been discussed by MARTINEZ et al. (2000), CHICA-OlMO et al. (2007, 2013), KULCZYCKI and LiGAS (2007), CICHOCIŃSKI (2009), MONTERO et al. (2009), and COLAKOVIC and VUCETIC (2012). Geostatistical methods create various possibilities in spatial analyses of transaction data, but they cannot always be used due to the adopted assumptions and the imperfect nature of the real estate market.

\section{The possibilities of geostatistical methods in real estate market analyses}

The real estate market is a complex system where demand, supply and prices are the key considerations. Geostatistical methods can address and solve various problems on the real estate market, but they are applied mainly to model transaction prices. The above process generally relies on two key elements of a geostatistical analysis: modeling the structure of variations in transaction prices and estimating values in points or identified fields (zones) with the use of different kriging variants.

The spatial correlation between property prices in different locations is determined mainly by similarities in location features, such as availability, neighborhood, surroundings and function. Therefore, it can be assumed a priori that property transaction prices should be autocorrelated because the similarity of location also implies the convergence of the main price-forming factors. According to BOURASSA, CANTONI and HOESLI (2007), the spatial structure of prices can be investigated with the use of appropriate semivariogram models. The semivariogram function indicates the rate at which mutual interactions between variables decrease with an increase in distance. The variations in semivariogram values can be characterized by three parameters: the nugget effect, sill and range. The nugget effect is the apparent discontinuity in the semivariogram function. It represents total variance resulting from measurement error and variance over distances shorter than the intervals separating measurement points. The threshold value is a point at which the semivariogram function achieves a constant value without a successive increase in its value. A general model that would effectively approximate the spatial correlations between property prices in each case is difficult to identify (DUBIN et al. 1999; GELFAND et al. 2004). A spherical model is generally applied (BASU and THIBODEAU 1998; GILLEN et al. 2001), but an exponential model may be more appropriate in some cases due to spatial and planning considerations, and pricing trends on the real estate market (CHICA-OLMO 2007). The exponential model is recommended when non-stationary random fields demonstrate a spatial trend. The trend is removed to reveal the actual range of spatial correlation between data. Figure 1 presents an isotropic semivariogram illustrating the spatial structure of prices of undeveloped land in Olsztyn, which has been zoned for residential construction. An assessment of price variations as a function of distance supports the determination of spatial correlations and limits of similarity based on the distance between properties. The range of the semivariogram for undeveloped land zoned for residential construction was estimated at 2,500 m, which implies that spatial correlations observed in excess of that distance are relatively insignificant. The above could be of significance during individual valuations that rely on the substitution principle.

The spatial structure of transaction prices is characterized by anisotropy. Prices do not change uniformly in all directions due to the unique attributes of space, in particular in urban areas. The anisotropic character of transaction prices was discussed by ANDO and UCHIDA (2004) and GILLEN et al. (2001) who attributed the above to spatial features, including freeways, traffic routes and railway 
lines. Transaction prices and, consequently, the value of real estate are influenced by the distance between the property and important locations, measured by driving or commuting time. The above explains the spatial variation in prices resulting from the distance between property and a railway station (such as the Fast Municipal Railway station in the Tricity area) or a subway station. Anisotropy induces differences in semivariogram functions, subject to the analyzed direction.

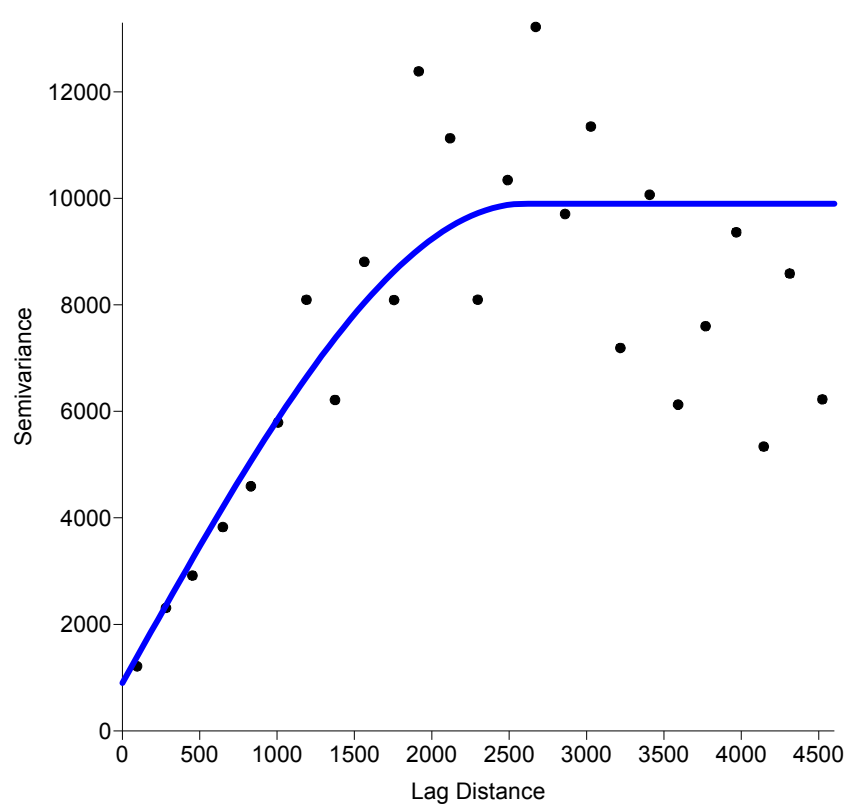

Fig. 1. A semivariogram of prices of undeveloped land in Olsztyn zoned for residential construction. Source: own elaboration.

Semivariogram modeling constitutes a basis for special interpolation with the use of kriging methods. The results of a spatial analysis of land prices performed with the use of selected kriging methods are presented in Figure 2.

In spatial analyses of the real estate market, geostatistical methods can be used for modeling spatial structure and kriging interpolation. Semivariance models of transaction prices support:

- evaluations of local variance (measured by the nugget effect),

- evaluations of spatial variation,

- determination of the correlations between location and price,

- determination of the limits of similarity based on the price criterion (measured by the range of the semivariance function).

The application of kriging methods for modeling transaction prices facilitates:

- the development of isoline maps or zone maps (block kriging) of property value,

- the estimation of interpolation errors and their spatial distribution,

- the development of maps describing the probability of specific transaction prices,

- the identification of high-value (or low-value) areas,

- evaluations of the continuity of spatial correlations.

Above all, geostatistical methods directly account for the location factor in quantitative analysis, which can significantly improve the quality of predictions in both individual and mass appraisal valuations.

\section{Limitations of geostatistical methods}

The use of geostatistical methods for modeling transaction prices does not always produce satisfactory results. The real estate market is governed by specific mechanisms, and methods that had been originally developed for mining and geology cannot always be applied to economic systems. The main problems stemming from the use of geostatistical methods in analyses of transaction prices are temporal and spatial non-homogeneity, and the influence of non-spatial factors of endogenous (physical attributes of property) and exogenous (legal and financial requirements associated with a property transaction) character. Transaction prices cannot be regarded as a physical attribute that is 
burdened by a measurement error. The main limitations of geostatistical methods in real estate market analyses are:
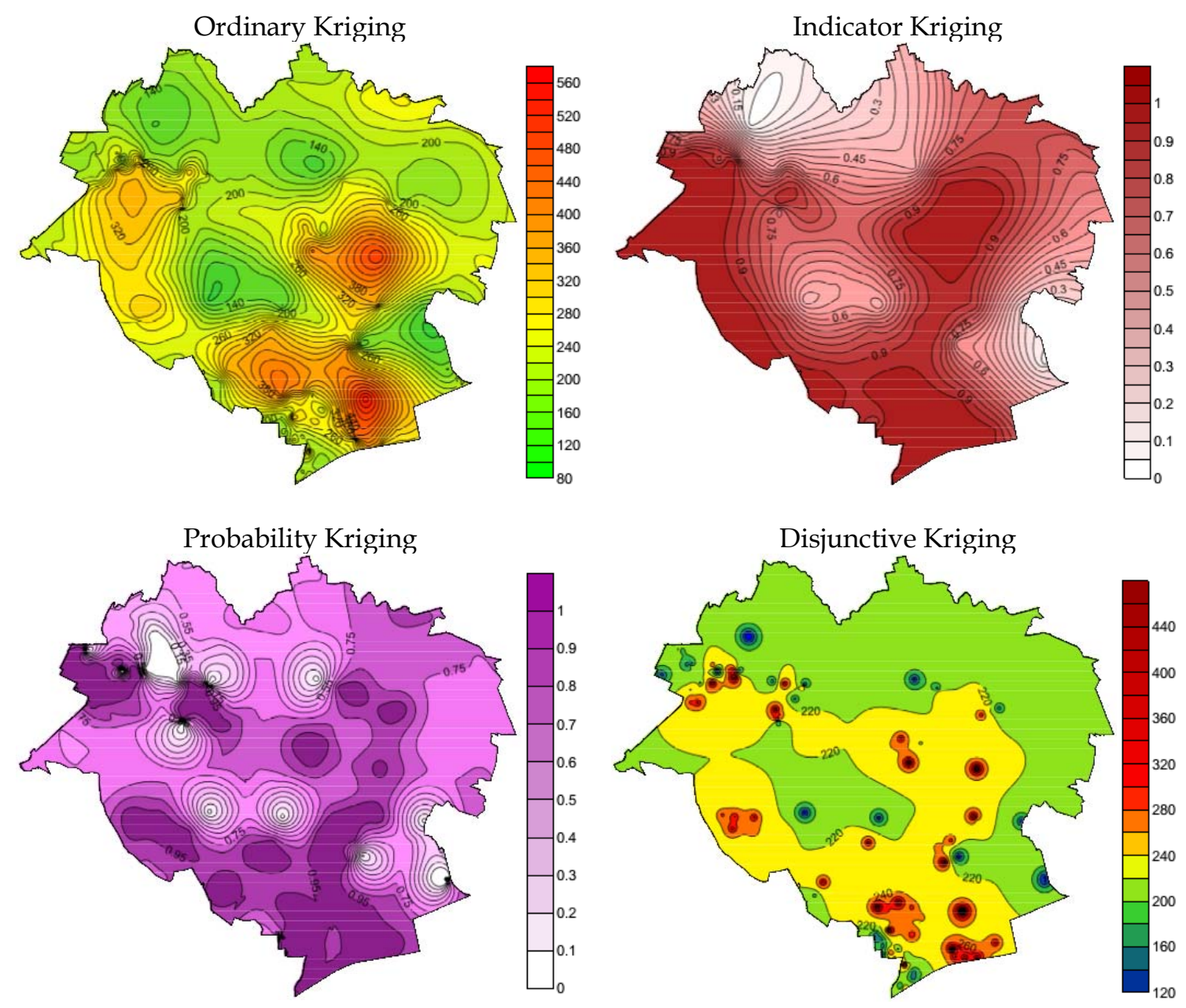

Fig. 2. The results of a spatial analysis of land prices performed with the use of various kriging methods. Source: own elaboration.

- the number and distribution of observations,

- non-continuity,

- non-homogeneity and the influence of non-spatial factors,

- relatively high price spread,

- changes in prices over time.

Above all, the analyzed data should be of satisfactory quality. Even a single divergent observation can falsify the regression model and produce considerable prediction errors in the entire analyzed area. Sufficient quantities of data are also required. An insufficient number of observations poses a significant problem when geostatistical and quantitative methods are applied. In many cases, a sufficient quantity of transaction data covering a relatively short period of time may be impossible to obtain. Some authors have postulated that semivariograms can be developed when at least 30 data pairs are available for every interval where semivariance is estimated (JOURNEL, HUIJBREGTS 1978). According to WEBSTER and OLIVER (2001), a minimum of 50 observations are required for semivariogram estimation. A small data set does not completely eliminate the use of kriging, but the results can be burdened by additional error due to insufficient information about price variance. The approximation of the semivariogram model and the three semivariogram parameters - the nugget effect, range and partial sill - significantly contribute to prediction errors. Special attention should be paid to spatial structure modeling, because this stage largely determines the shape of interpolated space as well as prediction errors. The differences between empirical and theoretical semivariograms can be expected to decrease with an increase in the number of observations. The form of the 
semivariogram can be very difficult to identify when limited data is available. In this case, several semivariograms should be calculated for differently sized class intervals to verify the stability of the resulting functions (KOKESZ 2010).

The spatial distribution of observation points is also an important consideration. If observation points do not reliably represent the analyzed area or represent only its central part, the resulting model will be burdened by significant errors, which will contribute to high prediction errors. This is particularly important because prediction variance increases significantly near the boundaries of the analyzed area. For this reason, observation points should be distributed evenly and, if possible, they should represent areas proximate to the boundaries. In general, real estate transactions are not evenly distributed in space. Transaction prices can be regarded as regionalized variables, but they represent a fact rather than measurement results. A prediction error can be evaluated based on geostatistical analyses, but the results will provide only generalized information about local price variations in a given point in space. The fact that a transaction was concluded in a given location has the most significant implications for the development of errors. The above can be attributed to the specific features of kriging estimation. Kriging variance is relatively low near transaction points (geometric centers of land plots). The problem of the uneven distribution of transaction points can be addressed by including additional data from individual valuations in the analyzed set of transaction prices. The correlations between the distance from neighboring points and kriging error can be used to estimate the location of additional data. The above correlation has been presented on the example of undeveloped land plots in Olsztyn in Figure 3. The estimation of additional market data is a laborious process; therefore, the analyzed objects should be separated by the greatest possible distance based on the adopted accuracy of prediction. The data presented in Figure 3 indicates that an increase in the above distance leads to greater prediction error, but the noted correlation is non-linear. The distance between the analyzed objects can be identified based on plotted points where the value of the prediction error begins to increase significantly.

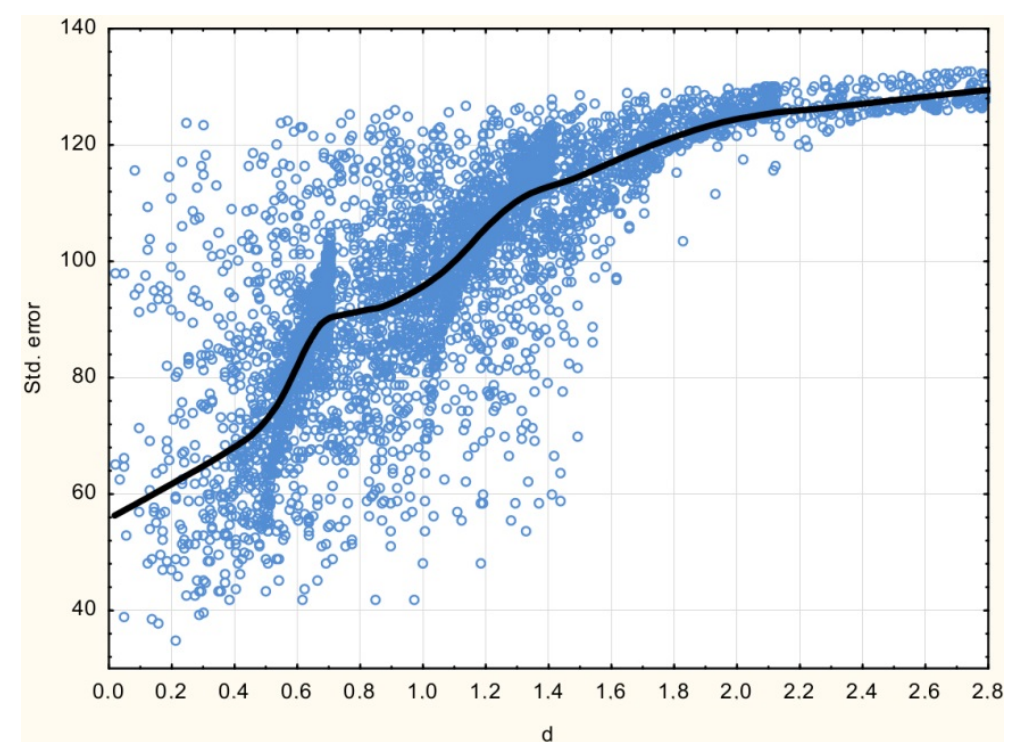

Fig. 3. The correlations between distance from neighboring points and kriging error. Source: own elaboration.

The maximum distance $d$ can also be estimated by analyzing the semivariogram range. The maximum distance should not exceed that range, but it can correspond to half the semivariogram range for the needs of spatial interpolation. The results of the analysis (Fig. 1) indicate that the semivariogram range of undeveloped land for residential construction is approximately $2.5 \mathrm{~km}$. In view of the adopted assumptions, the maximum distance $d$ between the analyzed objects should be somewhat greater than $1 \mathrm{~km}$.

A similar problem is encountered in the absence of information about transactions in areas with a high or low potential value of land. When the applied information relates only to completed transactions, the surface of the land value map may be excessively smoothed, and it will not faithfully represent local market trends. This problem can be partially solved by using additional variables that are highly correlated with transaction prices and characterized by spatial continuity (road access, 
noise, development density in the neighborhood). Cokriging methods support spatial interpolation based on information about additional variables. The results of spatial interpolation of transaction prices by ordinary cokriging with the use of information about development density in the neighborhood are presented in Figure 4. Development density in the neighborhood was estimated based on information about building location and total building area. The above task was accomplished with the use of a kernel density estimator based on a quartic (biweight) kernel defined by the following formula (SILVERMAN 1986, KULCZYCKI 2005):

$$
\hat{f}(x)=\frac{1}{m h^{2}} \sum_{i=1}^{m} 3 \pi^{-1}\left(1-\left(\frac{x}{h}\right)^{2}\right)^{2} \quad \text { for } \quad \mathrm{x} \leq \mathrm{h} \quad \text { and } \quad \hat{f}(x)=0 \quad \text { for } \quad \mathrm{x}>\mathrm{h}
$$

where:

m - size of a random sample

h $\quad$ - positive real number (smoothing parameter)

The development density map was plotted with a smoothing parameter of $500 \mathrm{~m}$.
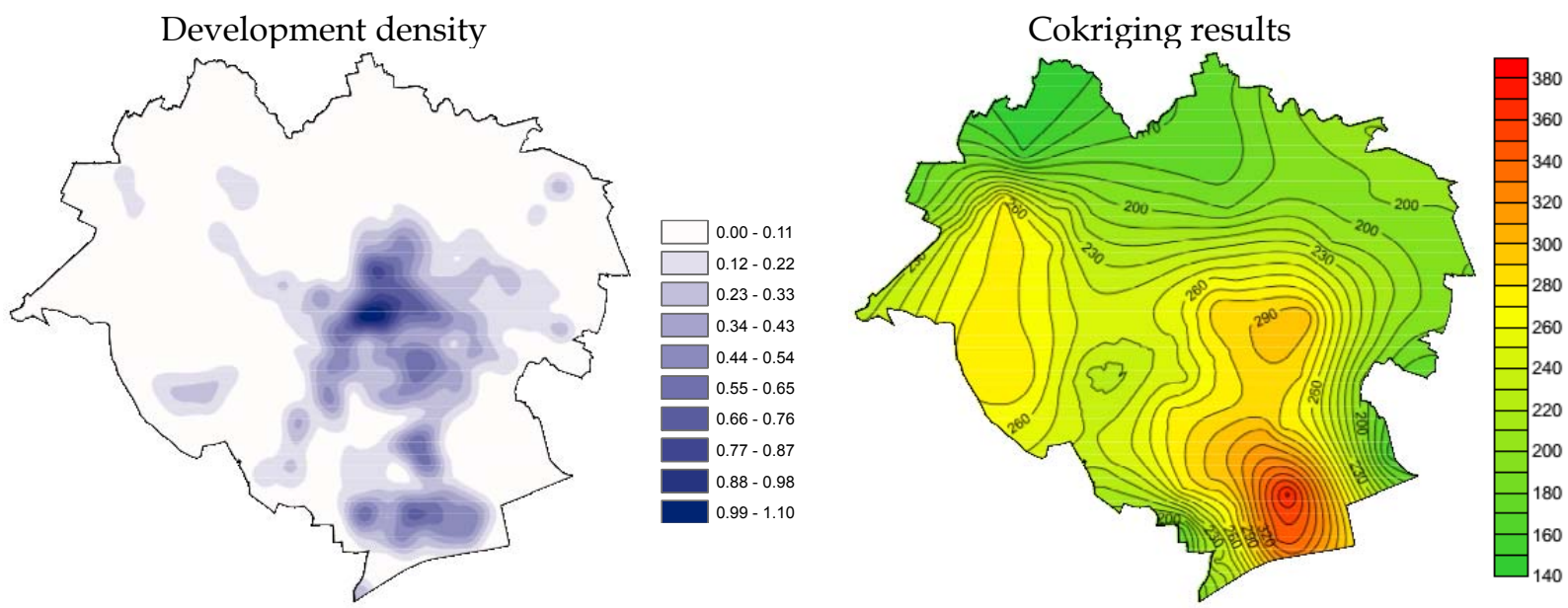

Fig. 4. Spatial interpolation of transaction prices by ordinary cokriging. Source: own elaboration.

The main problem encountered during the application of geostatistical methods is not only the distribution of transactions, but also their location relative to spatial barriers (rivers or railway lines). In this case, an independent geostatistical analysis should be carried out for every area delimited by linear objects.

Geostatistical methods are applied on the general assumption that the analyzed variables have a continuous character. In this case, continuity implies that the value of the variable can be measured (or read) in any point of the analyzed area, and that it changes gradually with distance (demonstrates spatial autocorrelation). The above assumption cannot be fully met on the market of undeveloped land due to, among others, various planning functions. Nearly every local real estate market incorporates areas whose value is not defined by spatial interpolation (surface waters, green areas, wasteland, etc.). The simplest solution would be to exclude those areas from analysis, but this does not solve the problem of spatial discontinuity, which significantly limits the application of geostatistical methods.

In principle, kriging interpolation should involve regionalized variables whose values are closely correlated with location. In analyses of real estate market data, location only partially explains the variation in transaction prices. Property prices are influenced by physical and legal attributes (ownership, function, etc.). In view of the above, preliminary analyses should be carried out to account for the influence of price-forming factors that are not directly related to location. Regression models are generally used, where the impact of location is reflected by the model's random component. The semivariance model and spatial interpolation methods are not directly developed for prices but for residuals (random components) of a model. Classical statistical models can be combined with geostatistical models to produce regression-kriging models, which, similarly to universal kriging and kriging with internal drift, are known as hybrid models (MCBRATNEY et al. 2000). Traditional models can also be combined with non-stationary geostatistical methods (WACKERNAGEL 1998, HENGL 
2007). Regression-kriging models have certain drawbacks relating to the fact that the coefficients of the regression model and the semivariogram function should be estimated simultaneously. The estimation of regression coefficients requires a knowledge of the residual covariance matrix, which can be determined only after the coefficients have been estimated. The above problem can be solved by calculating residuals and their covariance with the use of iterative methods, which have been described by SCHABENBERGER and GOTWAY (2005), and LIGAS (2009). Regression-kriging models seem to offer an effective solution in spatial modeling of economic phenomena (transaction prices and property value), but they have several limitations, and their application in spatial analyses of the real estate market is not always justified.

\section{Conclusions}

In comparison with other methods, geostatistical techniques are rarely applied in spatial analyses of economic phenomena on the real estate market. The above also applies to cokriging and regressionkriging methods that evaluate the impact of location on variations in property prices and take into account other price-forming factors.

The effectiveness of kriging methods for interpolation and the development property value maps is determined by the quality and reliability of data used in the process of developing semivariogram models. It should be noted, however, that the actual variations in prices and property values can considerably diverge from the values predicted by spatial interpolation, in particular when data is scarce and unevenly distributed. For the value of land on a local real estate market to be modeled effectively, the structure and source of price variations have to be interpreted correctly. Even the most effective quantitative methods do not eliminate the need for a qualitative assessment of certain phenomena that influence transaction prices. Geostatistical methods may facilitate the interpretation and analysis of the causes of price variations rather than serve as a tool for exploring the nature of the analyzed phenomenon.

\section{References}

ANDO A., UCHIDA R., 2004, The space-time structure of land prices in Japanese metropolitan areas, Annals of Regional Science, vol 38, pp. 655-674.

BASU S., THIBODEAU T., 1998, Analysis of spatial autocorrelation in house prices, Journal of Real Estate Finance and Economics, Kluwer Academic Publishers, vol. 17 (1), pp. 61-85.

Bourassa S. C., CANTOni E., Hoesli M., 2007, Spatial Dependence, Housing Submarkets, and House Price Prediction, Journal of Real Estate Finance and Economics, vol. 35, pp. 143-160.

CHICA-Olmo J., 2007, Prediction of Housing Location Price by a Multivariate SpatialMethod: Cokriging, Journal of Real Estate Research, vol. 29 (1), pp. 95-114.

Chica-Olmo J., Cano-Guervos R., ChicA-Olmo M., 2013, A Coregionalized Model to Predict Housing Prices, Urban Geography, vol. 34 (3), pp. 395-412.

CHILES J., Delfiner B., 1999, Geostatistics. Modelling Spatial Uncertainty, John Wiley \& Sons Inc.

CiCHOCIŃSKI P., 2009, Próba zastosowania metod geostatystycznych do taksacji nieruchomości, Roczniki Geomatyki, tom VII, z. 4(34), s. 17-30. (An attempt to use geostatistical methods for property taxation)

COlAKOVIC M., VuCETIC D., 2012, Possibility of Using GIS and Geostatistic for Modeling the Influence of Location on the Value of Residential Properties, FIG Working Week 2012, Rome, Italy, 6-10 May 2012, www.fig.net/pub/fig2012.

CRESSIE N., 1993, Statistics for Spatial Data, revised edition, John Willey \& Sons, New York.

DubIN R. A., 2003, Robustness of Spatial Autocorrelation Specifications: Some Monte Carlo Evidence. Journal of Regional Science, vol. 43, no 2, pp. 221-248.

Dubin R., Kelley PaCe R., ThiBodeau T. G., 1999, Spatial Autoregression Techniques for Real Estate Data, Journal of Real Estate Literature, vol. 7, American Real Estate Society, pp. 79-95.

Gelfand A. E., Ecker M. D., KNIGHT J. R., SiRMAns C. F., 2004, The Dynamics of Location in Home Price, Journal of Real Estate Finance and Economics, vol. 29, no 2, pp. 149-166.

Gillen, K., Thibodeau, T.G., Wachter, S., 2001, Anisotropic Autocorrelation in House prices. Journal of Real Estate Finance and Economics, vol. 23, no 1, pp. 5-30.

Hengl T., 2007, A Practical Guide to Geostatistical Mapping of Environmental Variables, European Commission, Joint Research Centre, Institute for Environment and Sustainability . 
IsaAKs E., SRIVASTAVA R., 1989, Applied Geostatistics, Oxford University Press.

Journel, A. G., HuijBreGTS, C.J., 1978. Mining Geostatistics, Academic Press Inc, London, UK

KOKESZ Z., 2010, Uwarunkowania stosowania krigingu zwyczajnego do sporzadzania map izoliniowych, Biuletyn Państwowego Instytutu Geologicznego, nr 439, s. 403-408. (Conditions of the use of ordinary kriging for isolinear mapping).

KRIGE D. G., 1951, A statistical approach to some mine valuations. Problems on the Witwatersrand, Journal of the Chemical Metallurgical and Mining Society of South Africa, December 1951, pp. 119-139.

KRIGE D. G., 1962, Statistical applications in mine valuation, J. Inst. Mine Survey South Africa, vol. 12 (2), pp. 95-136.

KUCHARSKA-STASIAK E., 1999, Nieruchomość a rynek, Wydawnictwo Naukowe PWN, Warszawa. (Real estate and the market).

KULCZYCKI P, 2005, Estymatory jądrowe w analizie systemowej, Wydawnictwa Naukowo-Techniczne, Warszawa. (Kernel estimators in the analysis of the system).

KULCZYCKI M., LIGAS M., 2007, Zastosowanie analizy przestrzennej do modelowania danych pochodzacych z rynku nieruchomości, Studia i Materiały Towarzystwa Naukowego Nieruchomości, vol. 15 nr 3-4, s.145-153. (Spatial analysis and real estate markets' modelling).

LigAS M., 2009, Zastosowanie modelu regresja-kriging do predykcji wartości nieruchomości, Studia i Materiały Towarzystwa Naukowego Nieruchomości, vol. 17, nr 1, s. 7-16. (Application of regression-kriging model to real estate value prediction).

LONGLEY P., GOODChILD M., MAGUiRE D., RHIND D., 2005, Geographic Information Systems and Science, John Wiley \& Sons Ltd, The Atrium, Southern Gate, Chichester.

MARTINEZ M. G., LORENZO J., RUBIO N., 2000, Kriging methodology for regional economic analysis: Estimating the housing price in Albacete, International Advances in Economic Research, vol. 6 (3), pp 438-450.

MATHERON G., 1963, Principles of Geostatistics, Economic Geology, no 58 pp. 1246-1266.

MATHERON G., 1971, The Theory of Regionalized Variables and its Applications, Les Cahiers du Centre de Morphologie Mathematique de Fontainbleau nr 5, Ecole Nationale Superieure des Mines de Paris.

McBratney A., ODeh I., Bishop T., Dunbar M., SHATAR T., 2000, An overview of pedometric techniques for use in soil survey, Geoderma 97 (3-4), pp. 293-327.

Montero, J.M., Larraz B., PAez A., 2009, Estimating Commercial Property Prices: An Application of Cokriging with Housing Prices as Ancillary Information, Journal of Geographical Systems 11 (4), pp. 407-25.

NAMYSŁOWSKA-WILCZYŃSKA B., 2006, Geostatystyka. Teoria i zastosowania, Oficyna Wydawnicza Politechniki Wrocławskiej. (Geostatistics. Theory and practice)

SARMA D. D., 2009, Geostatistics with Applications in Earth Sciences, Springer.

SCHABENBERGER O., GotWAy A. C., 2005, Statistical methods for spatial data analysis, Chapman \& Hall/CRC.

SilvermAn B.W., 1986, Density Estimation for Statistics and Data Analysis, New York, Chapman and Hall.

STACH A., 2009, Analiza i modelowanie struktury przestrzennej, [w] Zwoliński Z. (red.) GIS - platforma integracyjna geografii, Bogucki Wydawnictwo Naukowe, Poznań. (Analysis and modelling of spatial structure).

TU Y., H. SUn, S. YU, 2007, Spatial autocorrelations and Urban housing market segmentation, Journal of Real Estate Finance and Economics, vol. 34, pp. 385-406.

WACKERNAGEL H., 1998, Multivariate geostatistics: an introduction with applications, 2nd Edition, SpringerVerlag.

Webster R., Oliver M., 2001, Geostatistics for Environmental Scientists Statistics in Practice, Wiley, Chichester.

ZAWADZKI J., 2005, Wykorzystanie metod geostatystycznych w badaniach środowiska, Oficyna Wydawnicza Politechniki Warszawskiej. (Using geostatistical methods for environmental studies). 